(C) К.Г. Циплаков, В.Л. Денисенко, Ю.М. Гаїн, 2020

УДК 617:616.348-006.6-089-072.1

\title{
Лапароскопічна хірургія раку ободової кишки в практиці колопроктологічного відділення
}

\author{
К.Г. Циплаков ${ }^{1}$, В.Л. Денисенко ${ }^{1}$, Ю.М. Гаїн ${ }^{2}$ \\ УЗ «Вітебський обласний клінічний спеціалізований центр», Вітебськ, Республіка Білорусь ${ }^{l}$ \\ УО «Білоруська медична академія післядипломної освіти», Мінськ, Республіка Білорусь ${ }^{2}$
}

\section{Реферат}

Вступ. Захворюваність на колоректальний рак зберігається на високому рівні і має тенденцію до зростання. Колоректальний рак на третьому місці за поширеністю у чоловіків і на другому місці у жінок. У структурі смертності від раку дана нозологія посідає четверте місце. У Республіці Білорусь, за даними 2016 р., захворюваність на рак ободової кишки склала 31,6 на 100000 населення. Смертність від колоректального раку становить приблизно половину від захворюваності, в зв'язку з чим прогноз вважається відносно сприятливим. Частка радикально оперованих пацієнтів із колоректальним раком і питома вага пацієнтів, які перебувають під наглядом 5 і більше років 3 моменту встановлення діагнозу, мають тенденцію до зростання. Незважаючи на наявні позитивні тенденції, як і раніше спостерігається зростання захворюваності, а показники смертності, 5-річної виживаності та однорічної летальності все ще не можна назвати прийнятними.

Мета дослідження. Впровадження в клінічну практику і отримання власного досвіду лапароскопічних оперативних втручань із приводу раку ободової кишки.

Матеріали та методи. У проктологічному відділенні УЗ «Вітебський обласний клінічний спеціалізований центр» прооперовано 15 пацієнтів на рак ободової кишки. Діагноз раку ободової кишки підтверджений ендоскопічно 3 морфологічною оцінкою. Вік пацієнтів становив $64 \pm 8,8$ року, індекс маси тіла (BMI) $-25,6$ кг / м². Чоловіків було дев'ять (60\%), жінок шестеро (40\%). У 11 пацієнтів (73,3\%) спостерігалася коморбідна патологія в стадії компенса-

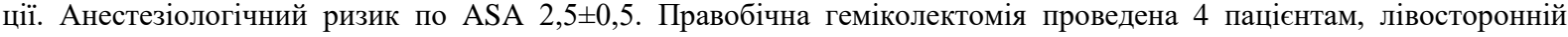
геміколектомія - 2 пацієнтам, резекція сигмовидної кишки - 7 пацієнтам, резекція ректосигмоїдного з'єднання - 2 пацієнтам. Обсяг виконаної лімфодисекції відповідав D2 у всіх пацієнтів.

Результати досліджень та їх обговорення. Всім 15 пацієнтам було успішно виконано лапароскопічну резекцію ободової кишки з приводу раку. Відзначено велику тривалість операцій, при цьому вони супроводжувалися малою крововтратою в більшості випадків. Апаратний анастомоз накладено у 8 пацієнтів, ручний - у 7 пацієнтів. Превентивні ілеостоми не накладалися. Післяопераційної летальності не було. Всім пацієнтам проведена багатокомпонентна анестезія, доповнена продовженою перидуральною анестезією. Конверсія на лапаротомію потрібна була в одному випадку. Легкі ускладнення I і II класу виникли у 3 (20\%) пацієнтів. Важке ускладнення V класу спостерігали в однієї пацієнтки (6,7\%). Тривалість післяопераційного інтенсивної терапії в РАО і післяопераційного періоду були невеликими. Відзначено швидке відновлення функції кишечника.

Висновки. Виконання радикальних лапароскопічних резекцій при раку ободової кишки обгрунтовано і технічно здійснимо з позицій онкологічного радикалізму. Ці втручання показують добрі безпосередні результати і повинні більш широко застосовуватися в клінічній практиці.

Ключові слова: колоректальний рак, лапароскопічна резекція, ободова кишка, мезоколонектомія, товстокишковий анастомоз.

Laparoscopic surgery of colon cancer in the practice of coloproctology department

K.G. Tsyplakov ${ }^{1}$, V.L. Denysenko ${ }^{1}$, Y.M. Gain ${ }^{2}$

Vitebsk regional clinical specialized center, Vitebsk, Republic of Belarus ${ }^{1}$

Belarusian medical academy of post-graduate education, Minsk, Republic of Belarus ${ }^{2}$

\section{Abstract}

Introduction. The incidence of colorectal cancer remains high and has a tendency to increase. Colorectal cancer is third in prevalence in men and second in women. In the structure of cancer mortality, this nosology takes fourth place. In the Republic of Belarus, according to data for 2016, the incidence of colon cancer was 31.6 per 100,000 population. Mortality from colorectal cancer is about half the incidence, and therefore the prognosis is considered relatively favorable. The proportion of radically operated patients with colorectal cancer and the proportion of patients who have been under observation for 5 years or more since the diagnosis was established tend to increase. Despite the positive trends, an increase in morbidity is still observed, and the mortality rate, 5-year survival rate and one-year mortality rate are still not acceptable.

Aim. Introduction into clinical practice and gaining own experience of laparoscopic surgical interventions for colon cancer.

Materials and methods. 15 patients with colon cancer were operated on at the proctology department of the Vitebsk Regional Clinical Specialized Center. The diagnosis of colon cancer was endoscopically confirmed with morpho-assessment. The age of the patients was $64 \pm 8.8$ years, body mass index (BMI) $-25.6 \mathrm{~kg} / \mathrm{m} 2$. There were nine men $(60 \%)$, six women $(40 \%) .11$ patients $(73.3 \%)$ had comorbid pathology in the stage of compensation. Anesthetic risk for ASA $2.5 \pm 0.5$. Right colectomy was performed in 4 patients, leftcolectomy in 2 patients, sigmoidcolon resection in 7 patients, resection of rectosigmoid compound in 2 patients. The volume of lymphadenectomy was D2 in all patients.

Results and discussion. All 15 patients successfully completed laparoscopic colon resection for cancer. A long duration of operations was noted, while they were accompanied by small blood loss in most cases. A stapler anastomosis was applied 
in 8 patients, manual in 7 patients. Preventive ileostomy was not superimposed. There was no postoperative mortality. All patients underwent multicomponent anesthesia, supplemented by prolonged epidural anesthesia. Conversion to laparotomy was required in one case. 3 (20\%) patients developed mild complications of I and II class. One patient (6.7\%) developed severe grade $\mathrm{V}$ complication. The duration of postoperative intensive care in the ICU and the postoperative period were short. Fast recovery of bowel function was noted.

Conclusion. Radical laparoscopic resection for colon cancer reasonable and technically feasible from the standpoint of oncological radicalism. These interventions show good immediate results and should be more widely used in clinical practice.

Key words: colorectal cancer, laparoscopic resection, colon, mesocolonectomy, colonic anastomosis.

Вступ. Захворюваність на колоректальний рак зберігається на високому рівні і має тенденцію до зростання. Колоректальний рак на третьому місці за поширеністю у чоловіків і на другому місці у жінок. У структурі смертності від раку ця нозологія посідає четверте місце. Стандартизований за віком показник смертності в світі дорівнює 8,2 на 100 000. Найбільш високі показники смертності в обох статей спостерігаються в Центральній i Східній Європі та складають 20,1 у чоловіків і 12,2 у жінок на 100 000. При цьому захворюваність досягає 89,8 на 100000 населення (Словаччина). У США найвищий показник смертності $(29,8$ на $100000)$ реєструється у чоловіків афроамериканців, а найбільш низький $(9,6$ на 100 000) у жінок на Тихоокеанських островах [1]. У Республіці Білорусь за даними на 2013 р. захворюваність на рак ободової кишки склала 26,9 на 100000 населення, до 2016 року цей показник зріс і склав уже 31,6 на 100000 населення. Смертність від колоректального раку становить приблизно половину від захворюваності, в зв'язку з чим прогноз вважається відносно сприятливим. Грубий інтенсивний показник смертності на 100000 населення склав 14,1 в 2016 р., а однорічна летальність $25,0 \%$ за цей же період. Частка радикально оперованих пацієнтів 3 колоректальним раком складає трохи більше 50\%, а питома вага пацієнтів, які перебувають під наглядом 5 і більше років 3 моменту встановлення діагнозу, склала у 2016 р. 49,4\%. Обидва ці показники мають тенденцію до зростання. Незважаючи на наявні позитивні тенденції, як і раніше спостерігається зростання захворюваності, а показники смертності, 5-річної виживаності та однорічної летальності все ще не можна назвати прийнятними [2].

Актуальність. Основним методом лікування раку ободової кишки є хірургічний. Вперше про проведення радикальної операції з приводу раку товстої кишки повідомили Maydl C. (1883р.) i Reybard J-F. (1884 p.). Подальші дослідження підкреслили важливість видалення не тільки органу 3 пухлиною, але проведення лімфодисекції. На відміну від хірургії раку прямої кишки, де загальноприйнятим стандартом виконання визнана тотальна мезоректумектомія (TME), запропонована R.J. Heald (1982р.), При раку ободової кишки все ще не розроблена стандартизована техніка операції. Це пояснює деякі відмінності в хірургічній техніці в різних клініках і країнах. У 2008 р. N.P. West зі співавторами показали, що резекція ободо- вої кишки в мезоколічному шарі підвищує 5-річну виживаність на $15 \%$, а при раку III стадії вона зростає до 27\% [3]. Набирає популярності ембріонально орієнтована хірургія. У даний час більшістю хірургів визнається і все частіше застосовується техніка повного видалення брижі ободової кишки в межах ембріональних шарів (CME) 3 центральним лігуванням живильних судин, розроблена W. Hohenberger $з$ співавт. (2009 р.) [4]. Схожі принципи, позитивно вплинули на результати лікування за рахунок збільшення кількості лімфовузлів, які видаляються при D3 лімфодисекції використовують японські автори [5]. Ведуться дослідження, які порівнюють онкологічні результати D2 і D3 лімфодисекцій [6]. Усі прогресивні підходи до хірургічного лікування спочатку застосовувалися до традиційних порожнинних втручань. У 1991 р. М. Jacobs вперше повідомив про початок пілотного проекту 3 освоєння лапароскопічних колектомій. Уперше були виконані лапароскопічні резекції як правих, так і лівих відділів і навіть прямої кишки, в тому числі і 3 приводу раку. Це поклало початок бурхливому розвитку лапароскопічної колоректальної хірургії. Багатьма науковими дослідженнями (Barcelona study, COST, COLOR, COLORII, CLASSIC, COREAN, JCOG0404, ACOSOG Z6051) показана онкологічна ефективність, безпека i технічна здійсненність практично будь-яких радикальних лапароскопічних операцій з приводу колоректального раку [9]. Основні переваги їх у порівнянні 3 відкритими втручаннями спостерігаються у найближчому післяопераційному періоді. Це низька інтенсивність больового синдрому, більш легкий перебіг післяопераційного періоду, менша летальність, кількість і тяжкість виникаючих ускладнень, хороші косметичні результати й ін. Віддалені результати можна порівняти 3 такими при традиційних відкритих операціях.

3 огляду на неухильне зростання захворюваності, поліпшення технічної оснащеності, розвитку скринінгових програм, радикальні оперативні втручання 3 приводу колоректального раку в практиці колопроктологічного стаціонару виконуються все частіше. Ця обставина вимагає від колопроктолога розуміння закономірностей перебігу онкологічного процесу і грамотного застосування правил надання онкологічної допомоги в своїй роботі. Це досягається за рахунок впровадження мультидисциплінарного підходу, взаємодії з фахівцями онкологами з питань навчання і надання спеціалізованої 
допомоги. Освоєння і неухильне дотримання принципів онкологічного радикалізму дає пацієнтові шанс на повне одужання, а мінімізація операційної травми за рахунок застосування лапароскопічних технологій дозволяє легше перенести хірургічне лікування і поліпшити його безпосередні результати. У Республіці Білорусь лапароскопічні резекції ободової кишки при ракові та неонкологічній патології освоєні лише в окремих клініках, що на сучасному етапі розвитку абдомінальної онкології і колопроктології не можна вважати достатнім [7, 8].

Згідно з Резолюцією XVI з'їзду хірургів Республіки Білорусь, впровадження та застосування лапароскопічних технологій для лікування захворювань і патологічних станів ободової і прямої кишки відноситься до «найближчих завдань колоректальної хірургії в Білорусі» [9].

Мета дослідження. Впровадження в клінічну практику і отримання власного досвіду лапароскопічних оперативних втручань із приводу раку ободової кишки, оцінка безпосередніх результатів застосування їх в умовах колопроктологічного стаціонару.

Матеріали та методи. У 2017-2019 рр. у проктологічному відділенні УЗ «Вітебський обласний клінічний спеціалізований центр» прооперовано 15 пацієнтів на рак ободової кишки. Показанння до лапароскопічної резекції виставляли при гістологічно підтвердженому діагнозі раку, відсутності ознак місцево поширеного процесу і дисемінації за клінічними і інструментальними даними. Пацієнтів 3 перфорацією і гострою кишковою непрохідністю в дослідження не включали. Всі інші протипоказання (ожиріння, спайковий процес, компенсована хронічна кишкова непрохідність та ін.) вважали відносними. Усім пацієнтам у повному обсязі було проведено обстеження згідно з прийнятим алгоритмом. За показами проводилася медикаментозна корекція коморбідної патології, при наявності компенсувалася анемія, білковий дефіцит. Діагноз раку ободової кишки був підтверджений ендоскопічно 3 морфологічною оцінкою. Ступінь диференціювання пухлини відповідав Grade 2 у всіх пацієнтів. Вік пацієнтів становив $64 \pm 8,8$ року, індекс маси тіла

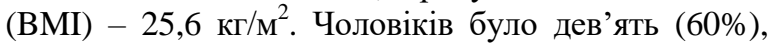
жінок шестеро (40\%). У 11 пацієнтів (73,3\%) була супутня ішемічна хвороба серця в стадії компенсації. Анестезіологічний ризик за ASA $2,5 \pm 0,5$. Розподіл пацієнтів за TNM представлено в таблиці 1.

Таблиця 1

Розподіл пацієнтів за TNM залежно від локалізації пухлини

\begin{tabular}{|c|c|c|c|c|c|c|c|c|c|c|}
\hline \multirow{2}{*}{\begin{tabular}{|c|} 
Локалізація пухлини \\
\end{tabular}} & \multirow{2}{*}{$\begin{array}{c}\begin{array}{c}\text { Всього } \\
\text { пацієнтів }\end{array} \\
15 \\
\end{array}$} & \multicolumn{4}{|c|}{ Рівень інвазії пухлни (Т) } & \multicolumn{3}{|c|}{$\begin{array}{c}\text { Оцінка ураження лімфа- } \\
\text { тичних вузлів (N) }\end{array}$} & \multicolumn{2}{|c|}{$\begin{array}{c}\text { Віддалені } \\
\text { метастази }(\mathrm{M})\end{array}$} \\
\hline & & $\mathrm{T} 1$ & $\mathrm{~T} 2$ & $\mathrm{~T} 3$ & $\mathrm{~T} 4 \mathrm{a}$ & N0 & N1a,b & $\mathrm{N} 2 \mathrm{a}$ & M0 & M1a \\
\hline Сліпа кишка & 1 & 0 & 1 & 0 & 0 & 1 & 0 & 0 & 1 & 0 \\
\hline Висхідна кишка & 3 & 0 & 1 & 0 & 2 & 0 & 0 & 1 & 0 & 1 \\
\hline Селезінковий згин & 1 & 0 & 1 & 0 & 0 & 1 & 0 & 0 & 1 & 0 \\
\hline Низхідна кишка & 1 & 0 & 0 & 0 & 1 & 0 & 0 & 1 & 1 & 0 \\
\hline Сигмовидна кишка & 7 & 1 & 1 & 2 & 2 & 4 & $\begin{array}{l}\text { N1a-2 } \\
\text { N1b-1 }\end{array}$ & 0 & 7 & 0 \\
\hline Ректосигмоїдний кут & 2 & 0 & 0 & 1 & 1 & 2 & 0 & 0 & 2 & 0 \\
\hline
\end{tabular}

За результатами проведеного обстеження і вивчення макропрепаратів за стадіями онкологічного процесу пацієнти були розподілені таким чином:

I стадія - 5 пацієнтів $(33,3 \%)$, II стадія - 4 пацієнти $(26,7 \%)$, III стадія - 5 пацієнтів $(33,3 \%)$, IV стадія - 1 пацієнт $(6,7 \%)$.

Залежно від локалізації пухлини були виконані такі оперативні втручання. Правобічна геміколектомія - у 4 пацієнтів, лівобічна геміколектомія - 2 пацієнтам, резекція сигмовидної кишки - у 7 пацієнтів, резекція ректосигмоїдного кута - 2 пацієнтам. Обсяг виконаної лімфодисекції відповідав D2 у всіх пацієнтів.

Усі оперативні втручання виконані однією бригадою хірургів за принципом ротації позиції 3 огляду на тривалість процесу засвоєння методики лапароскопічних резекцій. Використаний мультипортових доступ у всіх пацієнтів. Принципова розстановка троакарів і членів операційної брига- ди відрізнялася при резекції правих і лівих відділів ободової кишки. У разі правобічної резекції доступ в черевну порожнину здійснювали установкою першого троакара нижче пупка по середній лінії або справа параректально. Додатково встановлювали два троакара в правих відділах живота та один у лівій клубовій ділянці. Перевагу віддавали 10 мм троакар з редукційними перехідниками зважаючи на їх універсальності. Мобілізацію починали з виділення і кліпування a. et v. ileocolica, потім продовжували мобілізацію уздовж верхньої брижової вени, при їх наявності, кліпували і перетинали праві ободові судини. Елементи мезоколон відділяли від дванадцятипалої кишки і передньої поверхні головки підшлункової залози. Далі приступали до медіолатеральної мобілізації правої половини товстої кишки, перетинався великий сальник. Препарат витягувався через мінілапаротомію по середній лінії вище пупка. Права гілка 
середньої ободової артерії лігувати через мінілапаротомного рану. Також екстракорпорально виконувалася резекція і накладення анастомозу.

При виконанні резекції лівих відділів ободової кишки перший троакар вводили в ділянці пупка. Перевагу також віддавали 10 мм. Троакари 3 редукційними перехідниками. Додатково встановлювали троакар у правій клубовій ділянці, дещо медіальніше і вище передньоверхньої ості. Наступний троакар встановлювали параректально на рівні або трохи вище пупка, при цьому його позиція повинна бути медіальніше нижчестоящого для запобігання конфлікту інструментів при роботі в ділянці таза. 3 метою створення контртракції справа параректально встановлювали четвертий троакар. У разі необхідності мобілізації селезінкової згину встановлювали ще один троакар в епігастрії по середній лінії. Медіолатеральну мобілізацію починали 3 широкого розсічення парієтальної очеревини біля кореня мезоколон, просуваючись уздовж черевної аорти, ідентифікували та виділяли нижню брижову артерію. Останню кліпуровали на 1-1,5 см дистальніше основи 3 метою запобігання пошкодження гіпогастрального нервового сплетення. Мобілізацію мезоколон продовжували в краніальному напрямку і по ниж-

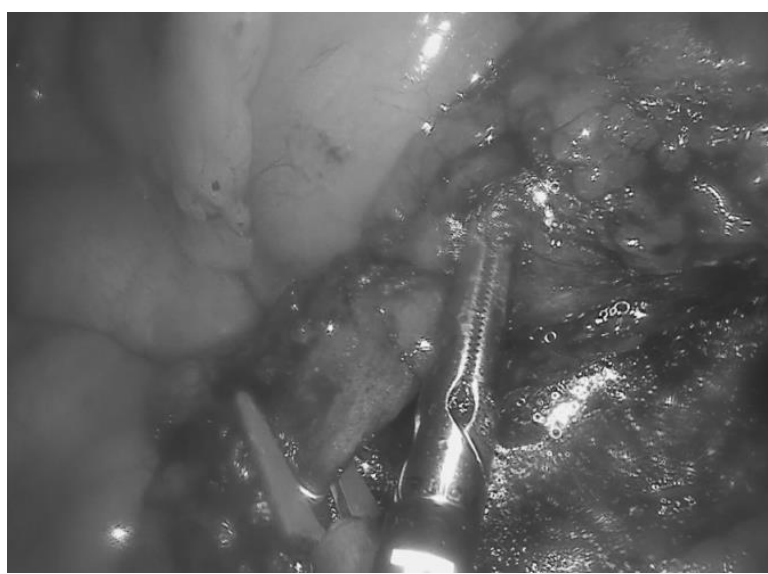

Рис. 1. Виконується кліпування нижньої брижової артерії на 1,5 см дистальніше основи.

Результати досліджень та їх обговорення. Усім пацієнтам було успішно виконана лапароскопічна резекція ободової кишки з приводу раку.

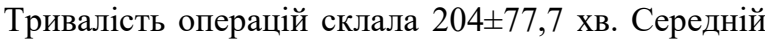
обсяг крововтрати 167 мл (від 20 до 800 мл). Апаратний анастомоз накладено у 8 (53\%) пацієнтів, ручний - у 7 (47\%) пацієнтів. Превентивні ілеостоми не накладалися. Післяопераційної летальності не було. Усім паціснтам проведена багатокомпонентна анестезія, доповнена продовженою перидуральною анестезією.

Конверсія на лапаротомію потрібна була в одному випадку. У пацієнтки з раком висхідної кишки при контрольній ревізії після проведення ре- нього краю підшлункової залози кліпуровали та перетинали нижню брижову вену. Після досягнення лівого бокового каналу приступали до розсічення очеревини в цій ділянці. Рутинну мобілізацію селезінкової згину не виконували, крім випадків із недостатньою довжиною анастомозуючих сегментів кишки, а також при локалізації пухлини в ділянці селезінкового згину або низхідної кишки. Препарат витягували через мінілапаротомію за Пфанненштилем або в лівій клубовій ділянці. Анастомоз накладали або екстракорпорально, при достатній довжині анастомозуючих сегментів кишки, або інтракорпорально під контролем лапароскопії циркулярним механічним швом, при цьому для перетину кишки i створення анастомозу використовували модифіковану для лапароскопічних операцій техніку C.D. Knight - F.D. Griffin (1990 р.) 3 використанням лінійного і циркулярного степлерів. Герметичність апаратного анастомозу перевіряли водно-повітряною пробою A.H. Davies (1988 р.) у всіх випадках.

Препарат вивчали, оцінюючи цілісність мезоколічної фасції, відстань від краю пухлини до країв резекції. Для гістологічного дослідження окремо відправляли не менше 12 лімфовузлів, які виявляли візуально і пальпаторно.

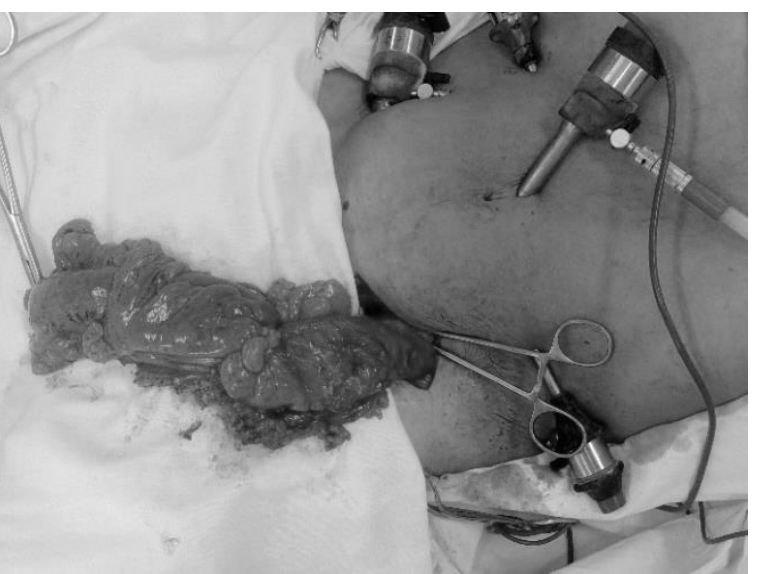

Рис. 2. Мобілізована сигмовидна кишка виведена через мінілапаротомну рану. Пухлина

визначається за втягненням в центрі препарату.

зекції і накладення анастомозу виявлені метастази до 10-15 мм в ділянці IV і VI сегментів печінки, які не вдалося виявити при попередній ревізії. Метастази визнані резектабельними. 3 огляду на відсутність досвіду лапароскопічної резекції печінки була виконана конверсія оперативного доступу на верхньо-серединну лапаротомію. Виконана атипова резекція зазначених сегментів печінки з метастазами.

Ускладнення зареєстровані у 4 пацієнтів $(26,6 \%$ випадків). Легкі ускладнення I і II класу за класифікацією Accordion (2009 р.) розвинулися у 3 (20\%) пацієнтів. У одному випадку спостерігалося нагноєння післяопераційної рани, що вимагало 
місцевого лікування, в іншому випадку в ході правобічної резекції виникла клінічно значима венозна кровотеча із зони стовбура Генле, що вимагало додаткової мобілізації в ділянці головки підшлункової залози для зупинки кровотечі, а також відбилося на стані гемодинаміки, що вимагало проведення заходів 3 боку анестезіологічної бригади зі стабілізації показників. Конверсії на лапаротомію і переливання компонентів крові не було потрібно. У третьому випадку на 2-у добу після резекції ректосигмоїдного кута виникла невелика кровотеча (не більше 150 мл) із зони апаратного анастомозу, яку купіровали призначенням гемостатичної терапії. Важке ускладнення V класу у вигляді неспроможності анастомозу після резекції сигмовидної кишки спостерігалося у однієї пацієнтки $(6,7 \%$ випадків). Причиною розвитку ускладнення послужило те, що в післяопераційному періоді у «вікні» брижі товстої кишки дислокувалася тонка кишка, що викликало порушення прохідності товстої кишки в цій зоні, натяг кишки в ділянці анастомозу. Ускладнення вимагало лапаротомії, роз'єднання анастомозу, виведення проксимальної колостоми. Необхідно відзначити, що в ході лапаротомії в клубової кишці виявлена щільна пухлина з групою збільшених регіонарних лімфовузлів. Один із них взято на гістологічне дослідження - діагностований синхронний нейроендокринний рак тонкої кишки III стадії. Проведена резекція клубової кишки в блоці з брижі й лімфовузлами.

Тривалість післяопераційного періоду в РАO склала 3,6 $\pm 1,6$ дня, в стаціонарі $13,6 \pm 6,3$ дня. Гази відійшли на 2,3 $\pm 0,83$ доби, стілець отримано на 4,5 $\pm 1,7$ доби. Призначення наркотичних анальгетиків треба було у двох $(13,3 \%)$ пацієнтів.

Висновки. Отримані результати свідчать про ефективність, відносну безпеку і технічному виконанні радикальних лапароскопічних резекцій у пацієнтів 3 раком ободової кишки, що відповідає даними інших авторів. Відзначено високу тривалість операцій і невелику крововтрату, невеликі терміни проведення інтенсивної терапії та стаціонарного лікування. Відновлення функції кишечника зазначалося в короткі терміни. Зареєстровано досить велику кількість ускладнень (26,6\%), однак важке ускладнення V класу було зареєстровано лише у одного пацієнта $(6,7 \%)$. Зазначені показники, ймовірно, будуть поліпшуватися в міру проходження «кривої навчання». Таким чином, необхідно подальше впровадження лапароскопічних втручань у хірургію раку ободової кишки, в тому числі в колопроктологічних відділеннях

Дослідження проводилося в рамках ініціативної теми НДР УО «ВГМУ» (номер державної реєстрації 20191550 від 02.07.2019 р.).

Інформація про конфлікт інтересів. Конфлікт інтересів відсутній.

Інформація про фінансування. Фінансової підтримки з боку компаній-виробників лікарських препаратів автори не отримували.

\section{Список використаної літератури}

1. Scholefield JH, Eng C. Kolorektal'nyy rak. Diagnostika i taktika lecheniya. [Colorectal cancer. Diagnosis and clinical management]. Moscow: Prakticheskaya meditsina. 2019; 277 (in Russian).

2. Okeanov AYe, Moiseyev PI, Levin LF, Yevmenenko AA, Sukonko OG. Statistika onkologicheskikh zabolevaniy v Respublike Belarus' (2007-2016). [Statistics of cancer diseases in the republic of Belarus (20072016)]. Minsk: RNPTs OMR im. N. N. Aleksandrova. 2017; 284 (in Russian).

3. West NP, Morris EJA, Rotimi O, Cairns A, Finan PJ, Quirke Ph. Pathology grading of colon cancer surgical resection and its association with survival: aretrospective observational study. Lancet Oncol. 2008; 9(9): 587565. DOI: https://doi.org/10.1016/S1470-2045(08)70181-5

4. Hohenberger W, Weber K, Matzel K, Papadopoulos T, Merkel S. Standardized surgery for colonic cancer: complete mesocolic excision and central ligation-technical notes and outcome. Colorectal Dis. 2009; 11(4): 354364. DOI: https://doi.org/10.1111/j.1463-1318.2008.01735.x

5. West NP, Kobayashi H, Takahashi K, Perrakis A, Weber K, Hohenberger W, Sugihara K, et al. Understanding optimal colonic cancer surgery: comparison of Japanese D3 resection and European complete mesocolic excision with central vascular ligation. Journal of Clinical Oncology. 2012; 30(15): 1763-1769. DOI: 10.1200/JCO.2011.38.3992

6. Karachun A, Panaiotti L, Chernikovskiy I, Achkasov S, Gevorkyan Y, Savanovich N, et al. Short-term outcomes of a multicentre randomized clinical trial comparing D2 versus D3 lymph node dissection for colonic cancer (COLD trial). Br J Surg. 2020; 107(5): 499-508. DOI: 10.1002/bjs.11387.

7. Vorobey AV, Makhmudov AM, Aleksandrov SV, Vysotskiy FM, Orlovsky Yu N, Butra YuV, et al. Laparoskopicheskiye operatsii na tolstoy kishke [Laparoscopic interventions in colon]. Zdravookhranenie. 2018; 6: 57-62. (In Russian) URL: https://elibrary.ru/item.asp?id=35234285

8. Slabadzin YuV, Adutckevich EA, Sidorov SA. Laparoskopicheskaya khirurgiya kolorektal'nogoraka v usloviyakh spayechnogo protsessa organov bryushnoy polosti. [Laparoscopic surgery of colorectal cancer under 
the conditions of adhesive process of the abdominal cavity organs]. Novosti Khirurgii. 2019; 27(3): 291-299. DOI: https://dx.doi.org/10.18484/2305-0047.2019.3.291 (In Russian)

9. Bogdan VG, Vorobey AV, Garelik PV, Dubrovshchik OI, Dundarov ZA, Marmysh GG, et al. Rezolyutsiya XVI s'yezdakhirurgovRespubliki Belarus' (1-2 nojabrja 2018 g., g. Grodno) [Resolution of the XVI Congress of Surgeons of the Republic of Belarus (November 1-2, 2018, Grodno)]. Novosti Khirurgii. 2019 Mar-Apr; 27(2): 232-239. (In Russian) URL: https://cyberleninka.ru/article/n/rezolyutsiya-xvi-sezda-hirurgov-respubliki-belarus1-2-noyabrya-2018-g-g-grodno

Стаття надійшла до редакції: 26.10 .2020 р. 